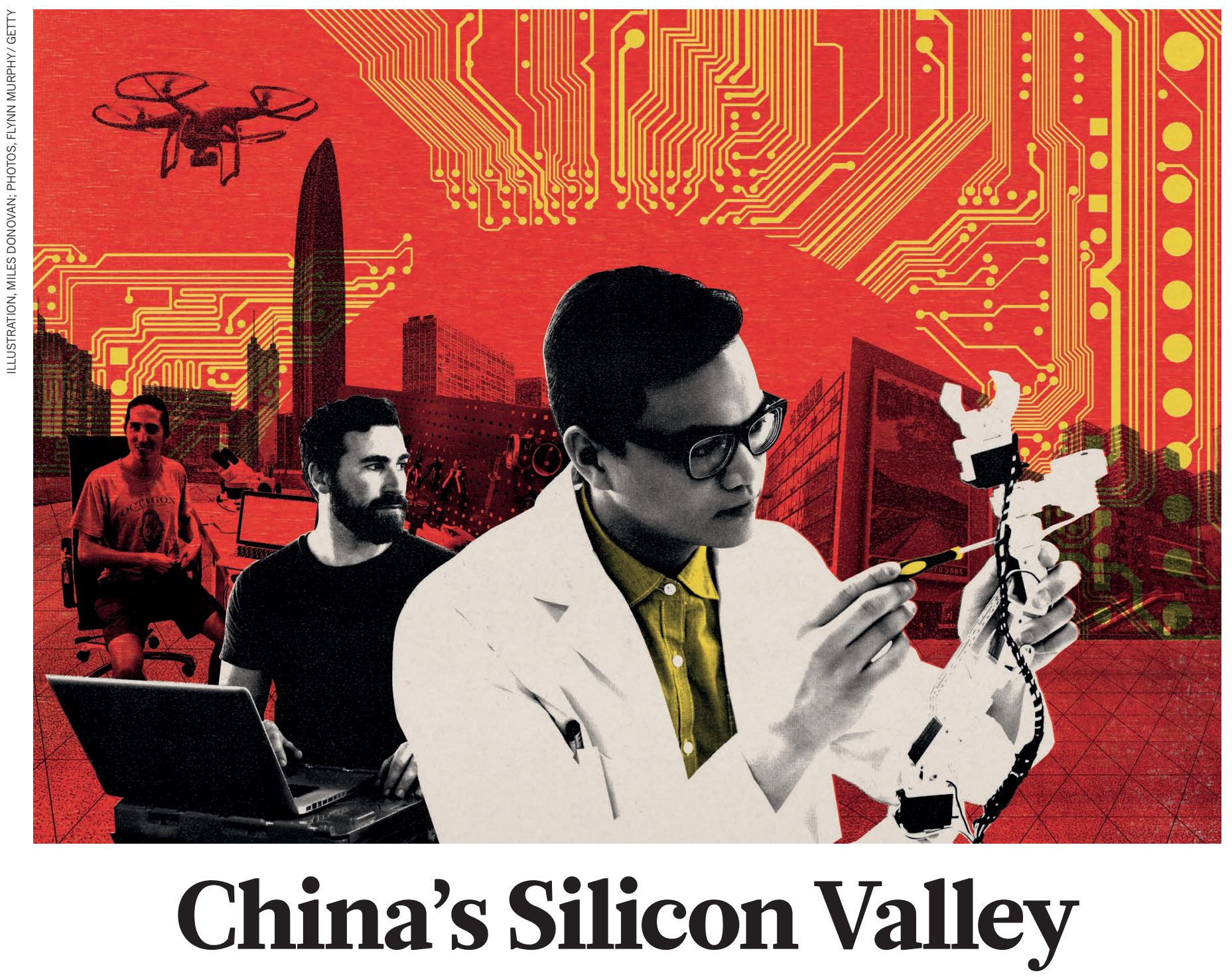

Shenzhen has emerged as a haven for biotechnology and cutting-edge hardware.

BY FLYNN MURPHY

$\mathrm{O}$ $\mathrm{n}$ a Sunday afternoon in March, children snake through the exhibits at the Shenzhen Science Museum in southeastern China. Two dozen have gathered in the foyer for a circuit-making demonstration led by a woman in her early twenties, who elicits answers and gently dissuades them from climbing on her desk.

In the main hall, a boy in blue overalls turns a wheel that controls the movements of a mechanical dog. Others admire a variety of rolling ball sculptures and play with robotic arms of the sort used in heavy industry. A girl of around five applauds a machine that generates tiny tornadoes out of vapour.

Two quotes in embossed metal command the wall above the main hall, in Chinese and English: "Imagination is more important than knowledge" (Albert Einstein), and "Innovation distinguishes between a leader and a follower" (Steve Jobs).
Imagination and innovation are ubiquitous motifs in the manufacturing powerhouse of Shenzhen. For decades, the city grew rich by manufacturing products designed overseas. Now, as wages rise and low-tech manufacturing drifts elsewhere, necessity has become the mother of invention for a city seeking a ticket out of a manufacturing slump.

\section{FROM FISHING TO CHIPS}

Shenzhen's rags to riches story has been told and retold. It was once Bao'an county, the fishing village across the border from Hong Kong that was chosen by China's de facto leader Deng Xiaoping in 1980 to be the country's first special economic zone - a place where foreign and domestic trade could take place without the explicit authorization of China's central government. Since then, Shenzhen has been flooded with thousands of foreign investors and millions of domestic workers hoping to improve their lot.
At last count, the city's official population was nearing 12 million.

Deng initiated the national policy of gaige kaifang - reform and opening up - in 1978. Now, this chain-smoking, five-foot titan of economic reform smiles down over Shenzhen's arterial Shennan Middle Road from a billboard - he faces a bike park brimming with various brands of privately rented bicycles, which can be unlocked by smartphone. Gaige kaifang has been supplanted by gaige chuangxin - reform and innovate. The slogan adorns everything from local government signs to bus-stop adverts for financial services.

Two of China's oldest universities, Peking and Tsinghua, have established small graduate outposts in the southwest of the city, in the picturesque Shenzhen University Town. But this is a young city with an even younger population - the average age is just shy of 30 - and it shows, in both its budding academic 
- sector and accompanying ambition. Take the Shenzhen Institutes of Advanced Technoloffshoot, which teaches mainly in English. In 2006 , it began as a team of five. Nine years later, SIAT was home to almost 2,000 academics and had signed a deal with the McGovern Institute for Brain Research at the Massachusetts Institute of Technology in Cambridge to establish the Brain Cognition and Brain Disease Institute. Overall, Shenzhen is home to around 90,000 university students, its government says.

But analysts suggest that scale and enthusiasm are not enough for the city's academic sector to compete on the national stage, and that the supercharged private sector is where the ground-breaking research is. "Shenzhen's been historically quite weak in terms of its academic reputation," says David Zweig, who researches China's efforts to attract scholars at the Hong Kong University of Science and Technology. "You're competing against a city like Beijing, which has Peking University, Tsinghua Univer-

What Shenzhen does get, Zweig says, is a lot of 'returnees' - Chinese citizens who have studied and spent an extended period in places such as the United States and Canada. Shenzhen is the key beneficiary of China's overseas studies programme, Zweig says. "They're getting back lots of really good people. And they're not so interested in manufacturing. They're more interested in hardware, IT, life sciences, biotech."

\section{HARDWARE HAVEN}

In a small workshop on the eighth floor of Huaqiang Electronics World's Building Number Two, Billy Frese is tinkering with his latest invention. The University of California, Berkeley bioengineering graduate explains how the Lief, ogy (SIAT), a Chinese Academy of Sciences sity ... Those are 100 years old."

a vibrating electrocardiogram patch that sits on the skin next to the heart, will help wearers to manage stress and anxiety by measuring the organ's electrical activity and responding with vibrations to guide the wearer's breathing. "It's kind of meditation on training wheels," he says.

Frese, who is the chief technology officer and part owner of Lief Therapeutics, has just returned from a trip to inspect conditions at a nearby battery factory. "I showed it to them, I said 'it goes over your heart", he motions, "so our batteries need to be safe."

Around 9\% of Lief Therapeutics has been

\section{SHENZHEN'S A PLACE WHERE YOU CAN VERY QUICKLY TURN AN IDEA INTO A PRODUCT.}

bought by the Shenzhen-based hardware accelerator HAX, which is in turn owned by the venture capital firm SOSV, based in Princeton, New Jersey.

In HAX's open-plan office, rows of mostly young, foreign teams are developing their own inventions, sandwiched between containers of protein powder and upside-down rucksacks. Benjamin Joffe - one of HAX's general partners - motions to an industrial robot arm about the size of a desk lamp, which he says is about to be bought by a major car manufacturer.

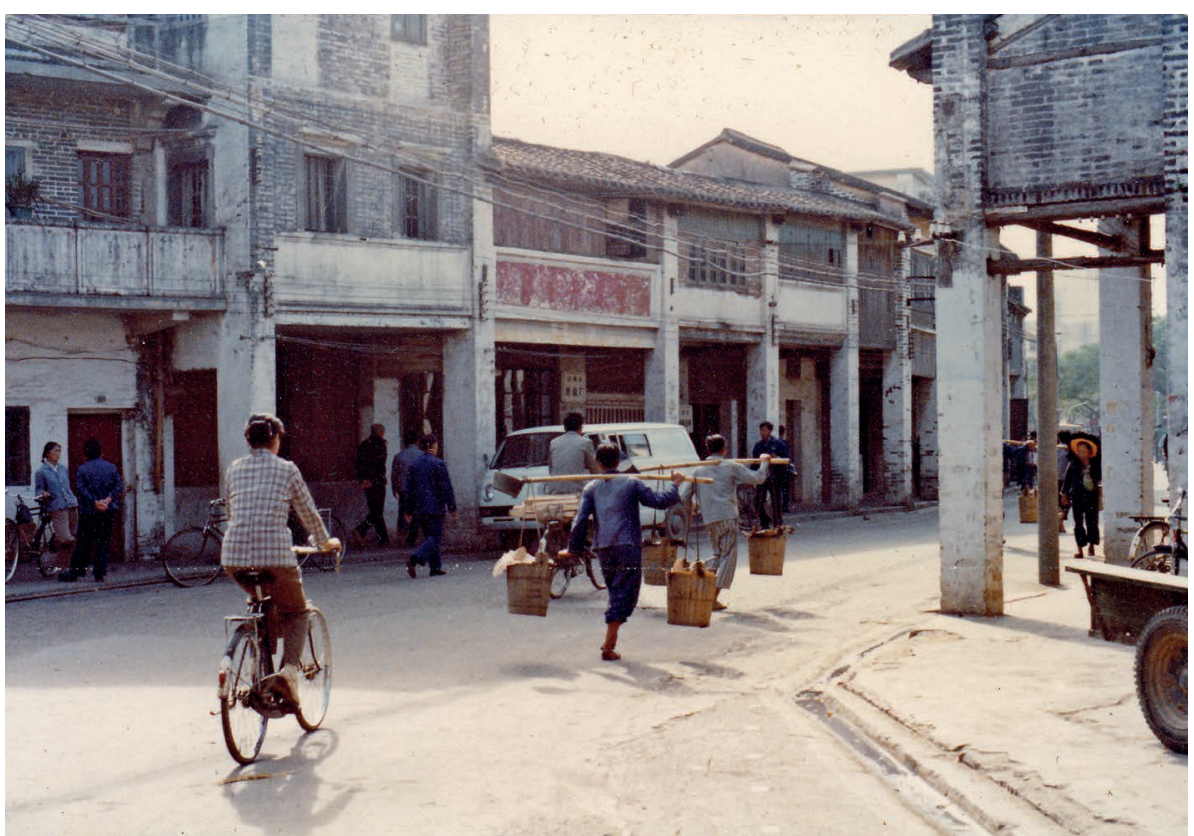

A Shenzhen street in 1979 , one year before Deng Xiaoping named the city a special economic zone.
HAX is in Shenzhen, says Joffe, because of the city's tech "ecosystem". "You need to have circuit manufacturers, you need to have the component supplier, the metal parts, the plastic parts, the coating, the certification testing, all those things in reasonable proximity." HAX's actual workshop is small because Shenzhen offers so many outsourcing options, he explains. And the extra capacity in the supply chain is a boon for inventors, with factories more willing to deliver on small-scale orders.

That same ecosystem breeds competition. Of around 1,000 hardware start-ups that apply to join the HAX programme each year, only 30 are successful.

\section{ELECTRIC AVENUE}

HAX is perched above what is often described as the world's largest electronics market. Huaqiangbei is better described as an electronics district. It's packed with market-malls of concrete and steel, some avant-garde in design, rising like giant computer chips from long causeways. In some, complete gadgets cables, computer keyboards, karaoke microphones, smartwatches - hang from every surface. More hang in the air, from remotecontrolled drones (Shenzhen is home to the world's largest drone manufacturer, DJI).

Others, like Building Number Two, look like a shipment of electronics has exploded, showering transistors, resistors, circuit boards and capacitors of every conceivable sort across floor after floor.

In alleys that wind behind the markets, white and yellow tarpaulin sacks better suited to rice and grain are packed full of components and machine parts, and loaded onto trucks and into the baggage compartments of commuter buses.

Nearby, perched on a bike and wearing a floral shirt, is delivery driver Li. The 45 -yearold took the 'English' name Sony — after the Japanese electronics manufacturer - when he moved to the city four years ago from regional Hunan. Sony has barely introduced himself when he begins a lecture on the finer points of the city's economic transition. He says lowskilled jobs are being sent offshore to parts of Africa, where he worked as a manager in a Chinese-owned manufacturing plant in Tanzania for half of last year. He returned because the money there was poor - around US $\$ 3$ a day.

\section{ENTREPRENEUR CITY}

"Shenzhen's a place where you can very quickly turn an idea into a product," says Blair Ney, a biomedical researcher at Monash University in Melbourne, Australia. Ney worked as an intern at a Shenzhen biomedical company in 2015. "The thing that stands out is how many people there are in an entrepreneurial mindset."

But Ney says that his basic level of Mandarin made life in the city alienating at times. Most of his interactions were with foreign entrepreneurs, on whom he saw "Chinese bureaucracy" take a toll. He notes that having connections 


\section{INTERNET POLICY}

\section{Frustrations with communication}

As elsewhere in China, researchers working in Shenzhen struggle with the Chinese central government's Internet censorship policy. Both Google and Facebook, for example, are blocked here.

"The work that I do requires a good connection to the rest of the world," says former Shenzhen resident Scott Edmunds, who edits Chinese genetics giant BGI's GigaScience journal. "It's one of the main reasons I moved to the Hong Kong office." (Hong Kong, although part of China, is in a unique position as a special administrative region. It has very little Internet censorship.) Edmunds says that using unreliable virtual private network (VPN) services to access the unfiltered web was one of the biggest challenges of his time in Shenzhen.

Australian mechatronics engineer Mike Reed says that there are far more opportunities for engineers in the city than back home. But like Edmunds, he finds Internet issues to be a continual source of frustration. Reed, who works for the hardware accelerator HAX and has an interest in biodegradable circuit design, has been in Shenzhen for around two-and-a-half years.

"The VPN issue is such an intermittent problem," he says. "One day you can have lightning fast speeds, you're streaming at like 1080p. And the next day you can't even open your e-mail account. I would say it's the thing that frustrates me most."

Although China blocks web traffic, it has a more complex relationship with VPN services. Chinese state media organizations have Facebook accounts, and the official newspaper of the ruling Chinese Communist Party has an active channel on blocked-by-default YouTube. F.M. with people who know the system is essential to success.

Ali Muhammad, an electrical and computing engineer, moved from Hyderabad in India to Shenzhen in 2009. He remembers the intense energy the first time he set foot in Huaqiangbei market. "I was very excited. You can buy anything from a single chip to the latest complete cell phones and accessories," although, he says, "you need to be careful" not to buy low-quality fakes.

Muhammad was working for Pakistan's National Telecommunication Corporation when he was selected for a training programme in the headquarters of Shenzhenbased telecoms giant Huawei.

Now completing a PhD in Canada, Muhammad was deeply impressed by the technology he saw there. The social experience, too: "It was truly multicultural - almost every neighbour was from a different country."

\section{BIOTECHNOLOGY BOOM}

Shenzhen might be a young city, but China is going grey. World Economic Forum figures suggest that by 2050 , close to 500 million Chinese citizens will be over 60 years old. Onethird of those will be over 80 . It's no stretch to predict an increase in chronic diseases such as dementia on a troubling scale.

Enter Shenzhen. A decade ago the Chinese genetics giant BGI (previously Beijing Genomics Institute) moved here from the nation's capital. BGI now has more than 5,000 staff worldwide, with 4,000 at the Shenzhen headquarters, and around 150 in a Hong Kong office that focuses on international sequencing.

Scott Edmunds has watched Shenzhen's life-sciences scene evolve over seven years at
BGI. Edmunds, who trained in cancer molecular pathology at Queen Mary University of London, was headhunted in 2010 to run BGI's GigaScience journal (see 'Frustrations with communication').

In recent years, he notes, a number of exBGI staff have struck out on their own, with some setting up rival companies and others maintaining good relations with the parent group, enriching the overall biotech scene.

Edmunds says that iCarbonX, founded by former BGI chief executive Jun Wang when he departed the company with around 100 other experts, falls into the latter category. Using genomics data collected by BGI from medical imaging and health records, it is making efforts to wed artificial intelligence with health care.

A massive new biotech hub has sprung up 50 kilometres east of Shenzhen's city centre in Dapeng New District. It's home to China's first national gene bank, which opened in September as a public-private partnership between BGI and the local government. Local media reports claim it could store 60 petabytes of data - enough space to save the entire written works of humanity in all languages since the beginning of recorded time or, in more modern language, around 800 years of backto-back high-definition film.

For foreigners who cope well with change, Edmunds says that there are plenty of opportunities in the city. "Salaries haven't quite caught up," he says, "but they've got mass overcapacity of computers. [They've got] state of the art imaging centres. It's a bit of a nerd's paradise. If you're a tech nerd, it's heaven." -

Flynn Murphy is a freelance reporter based in Beijing. 